\title{
ETHNOPRIMATOLOGY: HUMAN-MACAQUE INTERFACE IN THE UNIVERSITY OF MALAYA CAMPUS
}

\author{
Koh. $\mathbf{W}^{1 \mathrm{a}}$ and Y. Norma Rashid ${ }^{2 \mathrm{a}^{*}}$
}

anstitute of Biological Sciences, Faculty of Science, University of Malaya, 50603 Kuala Lumpur, MALAYSIA. Email: wenyuh94@gmail.com ${ }^{1}$; ynorma@um.edu.my²

Corresponding author: wenyuh94@gmail.com

Received: $4^{\text {th }}$ Jan 2019

Accepted: $23^{\text {rd }}$ Aug 2019

Published: $31^{\text {st }}$ Oct 2020

DOI: https://doi.org/10.22452/mjs.vol39no3.2

\begin{abstract}
Studies on human and primate interactions have been very popular but this is the first of such work examining a local scenario within a city campus in Malaysia. A study conducted in University of Malaya (UM) campus on the human and macaque interface showed that undergraduates from Year 1 to Year 4 had similar perceptions and experiences with macaque disturbances and consequences. It was significantly perceived that foraging had caused the macaques to enter residential colleges or faculties. A high percentage of students opted for macaque translocation to curtail the problem. The two focused macaque groups consumed different proportions of natural and artificial food, scavenged or offered, in their natural habitat. Natural food consumed by these animals consisted of petioles, leaves and fruits from different species of plants whereas the artificial food included the types consumed by humans. The major anthropogenic disturbance on the macaque groups was human presence (their approaching the animals or being nearby). Findings from this work conclusively revealed that the commonly perceived undesirable impact of macaques onto human beings also happened reciprocally from humans to macaques.
\end{abstract}

\begin{abstract}
ABSTRAK Kajian tentang interaksi manusia dengan primat adalah sangat popular tetapi ini merupakan kali pertamanya dijalankan dalam kampus tempatan Malaysia. Satu kajian yang dijalankan dalam kampus Universiti Malaya (UM) atas pertalian manusia-primat menunjukkan mahasiswa Tahun 1 hingga 4 mempunyai persepsi dan pengalaman mengenai gangguan kera dan kesan gangguan kera yang hampir sama. Mereka berpendapat bahawa pencarian makanan merupakan faktor utama kemasukan kera ke kolej kediaman dan fakulti serta bersetuju kaedah tangkap pindah dapat mengurangkan gangguan kera tersebut. 2 kumpulan fokus kera dalam kajian ini mempunyai diet pemakanan yang berlainan dari segi perkadaran makanan semulajadi dan buatan. Bahagian makanan semulajadi yang dimakan oleh kera dalam kajian ini termasuk daun, buah dan tangkai daun manakala makanan buatan termasuk makanan manusia. Gangguan manusia yang utama terhadap kera adalah kehadiran manusia (menghampiri atau berdekatan). Hasil kajian menunjukkan bahawa impak yang tidak diingini yang biasa dilihat dari kera ke atas manusia juga berlaku secara timbal-balik dari manusia ke kera.
\end{abstract}

Keywords: Macaque disturbances, natural food, artificial food, anthropogenic disturbance onto macaques

\section{INTRODUCTION}

Macaca fascicularis, commonly known as the long-tailed macaque, is the most widespread non-human primate species in the world (Fooden, 1995). They are widely distributed throughout the whole of Peninsular Malaysia, Sabah, Sarawak as well as 
throughout the Southern Asia: lower north of Thailand, Myanmar, southern Laos, Cambodia, Vietnam, Sumatra, Java and the Philippines (Malaivijitnond \& Hamada, 2008; San \& Hamada, 2009). Their broad ecological plasticity enables them to exploit anthropogenic environments and coexist with humans, which result in frequent associations with them and this eventually leads to humanmacaque conflicts.

The typical pest behaviours of macaques such as physical aggression towards humans, snatching their bags, entering and damaging their properties, stealing their food and other items as well as messing up garbage bins (Jones-Engel et al., 2011; Md-Zain et al., 2014) are regarded as dangerous and a nuisance to humans (Priston \& McLennon, 2013).

Macaques that have minimum associations with humans tend to be frugivorous (Ungar, 1994; Yeager, 1996). When fruit is not available, their diet will shift to insects, stems, young and mature leaves, flowers, seeds, grass, mushrooms, invertebrates, bird eggs, clay and bark (Wheatley, 1980; Yeager, 1996; Son, 2003). Macaques that inhabit mangrove areas were reported to have consumed crabs, frogs, shrimps and octopuses (Sussman \& Tattersall, 1986; Son, 2003). Due to shrinkage of habitats, they also exploit anthropogenic food resources in human altered areas. Anthropogenic food may make up a significant proportion of the diet of macaques such as those troops ranging in temples and tourist attractions (Hadi et al., 2007; Fuentes et al., 2011).

Human alterations on the landscape including forest modification, road construction, and preferential use of specific forests or other habitat areas have caused direct and indirect impacts on the macaques. The impacts of anthropogenic influence on them are variable and can be extensive. Recent studies have shown that anthropogenic disturbances consist of long-term effects across all aspects of macaque ecology and behaviour (Mckinney, 2015). Dietary and behavioural changes of the long-tailed macaques are prominent within human-altered environments and these include crop-raiding or rubbish stealing (Nijman \& Nekaris, 2010).

As Kuala Lumpur becomes increasingly urbanized, many wildlife species such as the long-tailed macaques are experiencing human induced habitat disturbances. The expansion of edge habitats and fragmented forests have exposed the macaques to numerous human settlements such as the UM campus where it is no longer unusual for residents to regularly encounter macaques due to a shared ecological and social area.

In Malaysia, there were researches of human-macaque interface which embraced both traditional primatology and social-cultural anthropology methods. However, few or none of the studies had reckoned with the welfare of the macaques along with that of humans. Therefore, it is timely to study the coexistence of humans and macaques at UM, using a novel dual approach, not only from human perceptions but also with concerns for the welfare of the macaques, in order to determine the impact of low and high anthropogenic macaque groups on humans to examine the feeding habits of these macaque groups as well as to investigate human impact on them.

\section{STUDY SITE AND METHODS}

\subsection{Study Site}

UM campus is located in the southwest of Kuala Lumpur and is approximately 373.12 ha. Long-tailed macaques are the most common wildlife that can be encountered in UM as the forest remnants serve as their natural habitat. The two study groups of macaques ranged in the Faculty of Science (Figure 1A) and the Faculty of Computer Science \& Information Technology grounds (Figure 1B). The group found in the Faculty of Science was identified as a highly anthropogenically affected group due to its very regular dan direct contact with humans while those seen in the Faculty of 
Computer Science \& Information Technology were identified as a low anthropogenically affected group because of their low level of contact with humans.

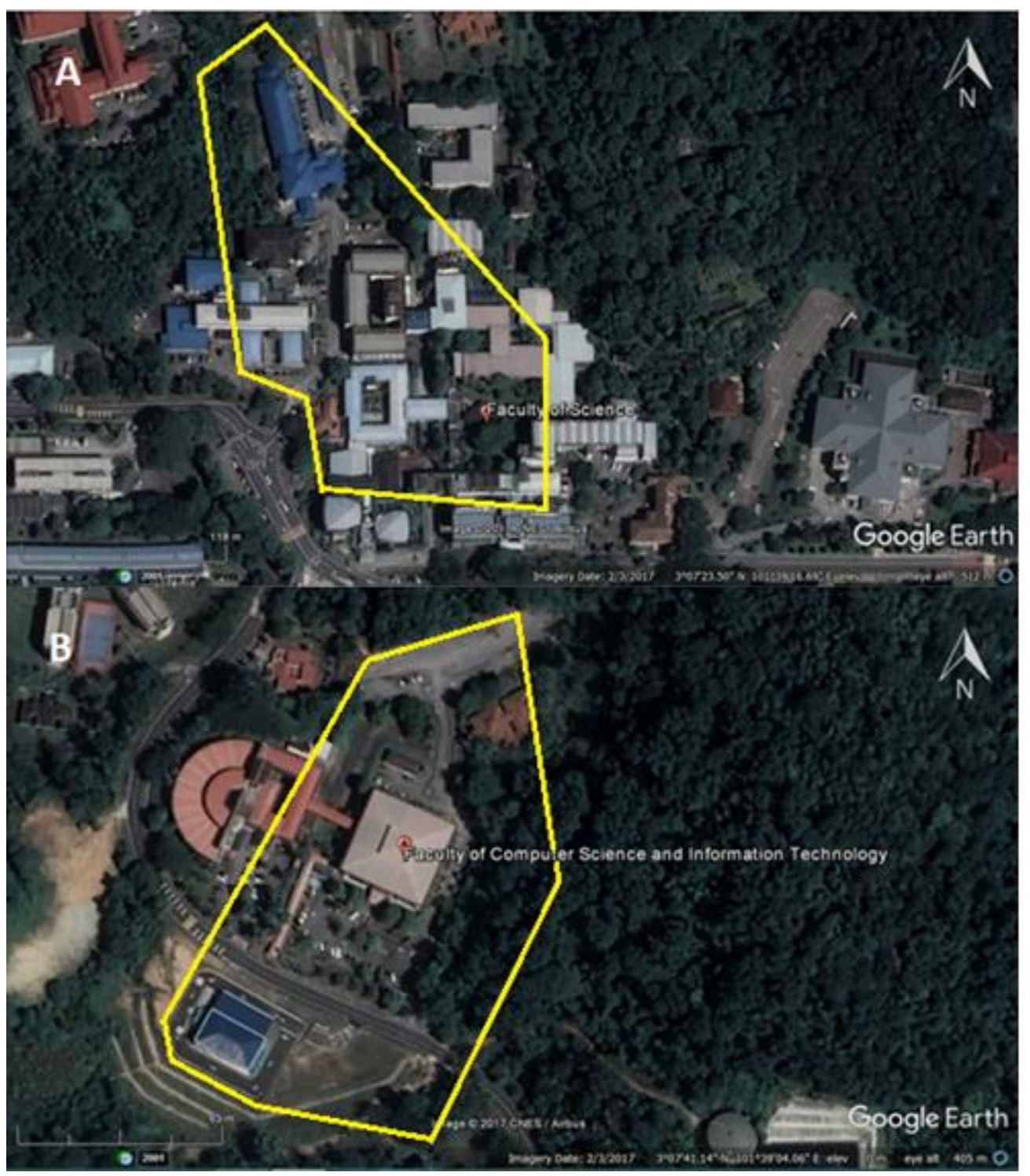

Figure 1. Ranging area of (A) high anthropogenic macaque group in Faculty of Science and (B) low anthropogenic macaque group in Faculty of Science Computer \& Information Technology, UM (Observation was done within the area of yellow polygons).

\subsection{Sampling Methodology}

A questionnaire survey was used in this study to find out the perceptions of UM students regarding the long-tailed macaques. The target group for the questionnaire survey consisted of undergraduates from Year 1 to Year 4. The questionnaire (Appendix A) was adapted (with modifications) from Hambali et al. (2012) and the questions were categorised into five (5) parts: (i) Respondent Information (ii) Macaque Disturbances (iii) Consequences of Macaque Disturbances (iv) Causal Factors and (v) Solutions to Overcome Problems. The questionnaires were distributed via SISWAMAIL to ensure random sampling and a total of 358 respondent data were used for data analysis.

Direct observation was used for this study whereby an interval scan sampling was carried out during the observational samplings. Two macaque troops were identified and observed for four (4) weeks between 1630 and 
1915 hours on days when available. This totalled up to 30 contact hours of observations for the behavioural data collection. Macaques within sight were observed and scanned at 5minutes interval from left to right to avoid repeated sampling. Their behavioural activity and diet were recorded and analysed. A preliminary observation was carried out to identify the behaviours exhibited by the macaques and the 29 behavioural acts displayed by the focused groups were identified and tabulated in a modified ethogram (Brent \& Veira, 2002) (Appendix B).

Plant samples were collected and a plant specialist was consulted for the identification of species level. Repository specimens in Rimba Ilmu, UM were used as references in the plant identifications. A statistical test (paired t-test) was used to analyse the questionnaire survey. The Kruskal Wallis test was used to analyse the behaviour of the macaques and the Chi square test was performed to compare the behaviours and feeding habits as well as the human impact on the macaque groups by using the PAST 3.16 software. P-values less than 0.05 consider statistically significant while greater than that consider non-significant (N.S).

\section{RESULTS AND DISCUSSION}

\subsection{Impact of Long-tailed Macaques (Low and High Anthropogenic Macaque Groups) on Humans in UM}

\subsubsection{Questionnaire Survey}

A total of 358 respondent results were obtained and analysed (Table 1). Based on the responses, we found that Year 1 to Year 4 students had similar perceptions, experiences and suggestions on macaque existence in UM campus. Paired t-test (Table 2a-2d) showed that there was no significant difference between the Year 1 to Year 4 respondents in the mean percentages of students' perceptions, experiences and suggestions on macaque existence in UM campus.

Table 1. Academic year distribution of respondents of the questionnaire survey.

\begin{tabular}{ccc}
\hline Academic Year & Number & $\%$ \\
\hline 1 & 161 & 45.0 \\
\hline 2 & 44 & 12.3 \\
\hline 3 & 71 & 19.8 \\
\hline 4 & 82 & 22.9 \\
\hline
\end{tabular}

Table 2a. Comparison between Year 1 to Year 4 students' experiences on macaque disturbances.

\begin{tabular}{|c|c|c|c|c|c|c|c|c|}
\hline \multirow{2}{*}{ Year } & \multicolumn{2}{|c|}{1} & \multicolumn{2}{|c|}{2} & \multicolumn{2}{|c|}{3} & \multicolumn{2}{|c|}{4} \\
\hline & $\mathrm{t}$ & $\mathrm{p}$ & $\mathrm{t}$ & $\mathrm{p}$ & $\mathrm{t}$ & $\mathrm{p}$ & $\mathrm{t}$ & $\mathrm{p}$ \\
\hline 1 & & & -1.37 & 0.23 & -1.19 & 0.29 & -0.09 & 0.93 \\
\hline 2 & & & & & 0.41 & 0.70 & 2.40 & 0.06 \\
\hline 3 & & & & & & & 1.75 & 0.14 \\
\hline 4 & & & & & & & & \\
\hline
\end{tabular}


Table 2b. Comparison between Year 1 to Year 4 students' perceptions and experiences on consequences of macaque disturbances.

\begin{tabular}{|c|c|c|c|c|c|c|c|c|}
\hline \multirow{2}{*}{ Year } & \multicolumn{2}{|c|}{1} & \multicolumn{2}{|c|}{2} & \multicolumn{2}{|c|}{3} & \multicolumn{2}{|c|}{4} \\
\hline & $\mathrm{t}$ & $\mathrm{p}$ & $\mathrm{t}$ & $\mathrm{p}$ & $\mathrm{t}$ & $\mathrm{p}$ & $\mathrm{t}$ & $\mathrm{p}$ \\
\hline 1 & & & -1.56 & 0.22 & -2.25 & 0.11 & -1.84 & 0.16 \\
\hline 2 & & & & & -2.72 & 0.07 & 0.37 & 0.74 \\
\hline 3 & & & & & & & 2.90 & 0.06 \\
\hline 4 & & & & & & & & \\
\hline
\end{tabular}

Table 2c. Comparison between Year 1 to Year 4 students' perceptions on causal factors of macaque disturbances.

\begin{tabular}{|c|c|c|c|c|c|c|c|c|}
\hline \multirow{2}{*}{ Year } & \multicolumn{2}{|c|}{1} & \multicolumn{2}{|c|}{2} & \multicolumn{2}{|c|}{3} & \multicolumn{2}{|c|}{4} \\
\hline & $\mathrm{t}$ & $\mathrm{p}$ & $\mathrm{t}$ & $\mathrm{p}$ & $\mathrm{t}$ & $\mathrm{p}$ & $\mathrm{t}$ & $\mathrm{p}$ \\
\hline 1 & & & 1.26 & 0.26 & -0.35 & 0.74 & -0.7 & 0.51 \\
\hline 2 & & & & & -1.74 & 0.13 & -2.13 & 0.08 \\
\hline 3 & & & & & & & -0.25 & 0.81 \\
\hline 4 & & & & & & & & \\
\hline
\end{tabular}

Table 2d. Comparison between Year 1 to Year 4 students' suggestions to overcome problems caused by macaques.

\begin{tabular}{|c|c|c|c|c|c|c|c|c|}
\hline \multirow{2}{*}{ Year } & \multicolumn{2}{|c|}{1} & \multicolumn{2}{|c|}{2} & \multicolumn{2}{|c|}{3} & \multicolumn{2}{|c|}{4} \\
\hline & $\mathrm{t}$ & $\mathrm{p}$ & $\mathrm{t}$ & $\mathrm{p}$ & $\mathrm{t}$ & $\mathrm{p}$ & $\mathrm{t}$ & $\mathrm{p}$ \\
\hline 1 & & & 2.08 & 0.08 & -0.01 & 0.99 & -0.25 & 0.81 \\
\hline 2 & & & & & -2.12 & 0.07 & -1.78 & 0.12 \\
\hline 3 & & & & & & & -0.35 & 0.74 \\
\hline 4 & & & & & & & & \\
\hline
\end{tabular}

\subsubsection{Category of Macaque Disturbances}

From the responses given, we found that Year 1 to Year 4 students had similar experiences on macaque disturbances (Figure 2). The highest percentage of students who were afraid of macaques was recorded among the Year 2 students $(68.2 \%)$, followed by Year $1(67.1 \%)$, Year $4(65.9 \%)$ and Year $3(63.4 \%)$. The highest percentage of students who had seen macaques roaming in residential colleges or faculties were from Year $3(98.6 \%)>$ Year 2
$(95.5 \%)>$ Year $1(92.5 \%)>$ Year $4(90.2 \%)$ The percentage of students in Year 1 (83.8\%) was the highest for having experienced direct disturbances from macaques such as being followed or approached, followed by Year 2 (81.0\%), Year 4 (79.6\%) and Year $3(76.1 \%)$. All the students in levels from Year 1 to Year 4 had been chased by macaques in UM, where the highest percentage was Year 2 (47.6\%), subsequently followed by Year $3(41.3 \%)$, Year $4(32.7 \%)$ and Year $1(23.8 \%)$. Among these undergraduates, only $4.3 \%$ of the Year 3 
students and $2.5 \%$ of the Year 1 students were bitten by macaques, while none from Year 2 or Year 4 had such injuries. For the category of witnessing macaques harassing people; the highest percentage was recorded among students from Year $3(83.1 \%)$, followed by Year $2(79.5 \%)$, Year $4(69.5 \%)$ and the lowest was for Year $1(67.1 \%)$.

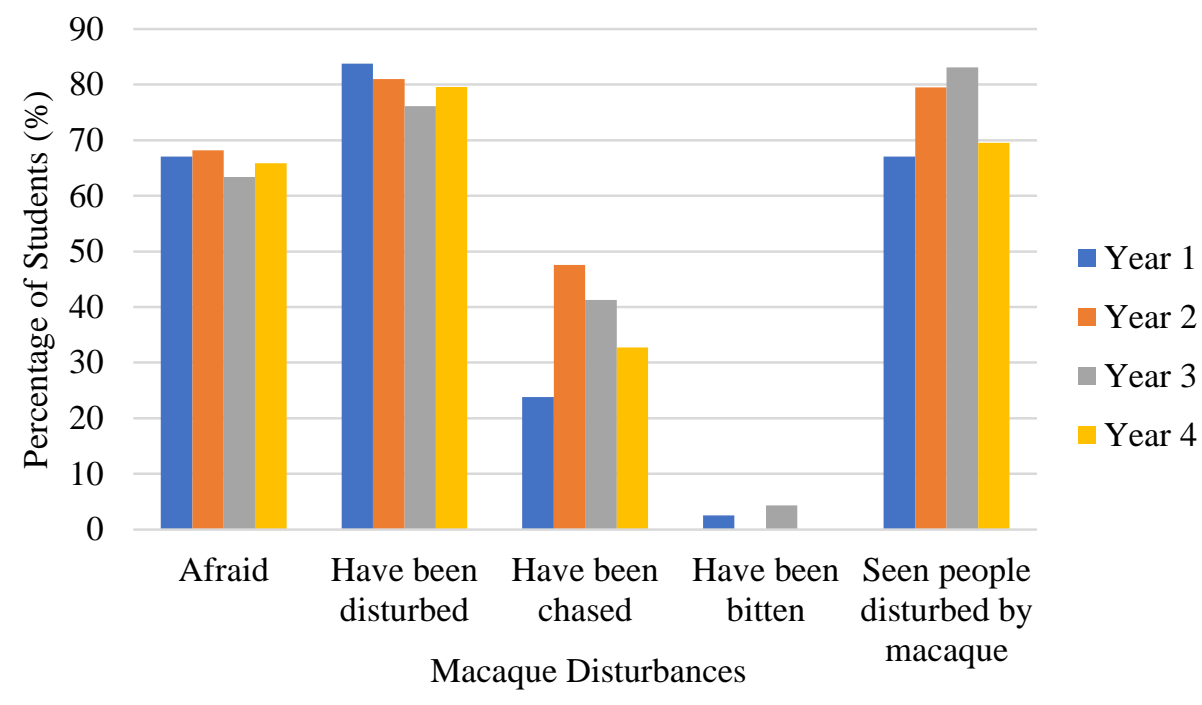

Figure 2. Percentage of students' having experienced or witnessed macaque disturbances.

We found that the mean percentages of students' perceptions, experiences and suggestions on macaque disturbances, consequences, causal factors and solutions to overcome the problems across the academic years were very similar, indicating that generally, they were all aware of the wildlife living in their surroundings and issues of animal welfare and wildlife conservation.

We found that the percentage of UM students who had experienced macaque disturbances was similar to that of the students in Universiti Kebangsaan Malaysia (UKM) (Md-Zain et al., 2014). More than 75.0\% of UM students from the four respective academic years had been disturbed by the macaques and there were cases where $2.5 \%$ of Year 1 and $4.3 \%$ of Year 3 students had been bitten by them. This might be the reason behind the high percentage of students (more than $60.0 \%$ ) being afraid of macaques. The high percentage of students (more than $65.0 \%$ ) that had witnessed people being disturbed by macaques, may have further contributed to the fearful feelings about macaques. Over $90.0 \%$ of UM students had seen macaques roaming around residential colleges or faculties because of the macaques' daily feeding and activities that usually start from 0900 to 1000 hours, 1200 to 1300 and again between 1400 to 1700 (Sussman \& Tattershall, 1981), which basically coincided with the time of student outdoor activities such as moving to lecture halls and the cafetaria or attending recreational activities.

\subsubsection{Category of Consequences of Macaque Disturbances}

Although the paired t-test showed no significant differences between the mean percentage of students experiencing consequences of macaque disturbances and their perceptions of them, yet, Figure 3 illustrates deviations between the years, whereby Year 3 students gave greater positive responses regarding macaque disturbances.

Undergraduates from all levels, ranging from $74.6 \%$ to $69.6 \%$, perceived that the 
macaques were considered pests due to their rummaging and littering acts in the residential colleges or the faculties. They postulated this will affect the safety and health of residents on campus (range from 81.7 to $72.7 \%$ ). At the same time, corresponding to the perceptions of the consequences of macaque disturbances, $60.6 \%$ of Year 3 students, the group with the highest percentage, had experienced episodes where macaques had entered their rooms. Some students had their things stolen by macaques either from their rooms or elsewhere during their stay on UM campus: $83.1 \%$ of Year 3, $79.5 \%$ of Year 2, $67.1 \%$ of Year 4 and $41.6 \%$ of Year 1. Any kind of food possessed by students was the prominent item taken by macaques, where more than $94.0 \%$ of students from each academic year had lost food stuffs to macaques. Other examples of belongings that were taken included daily necessities such as toothpaste, containers, clothes, socks, paper, crayons and makeup items.

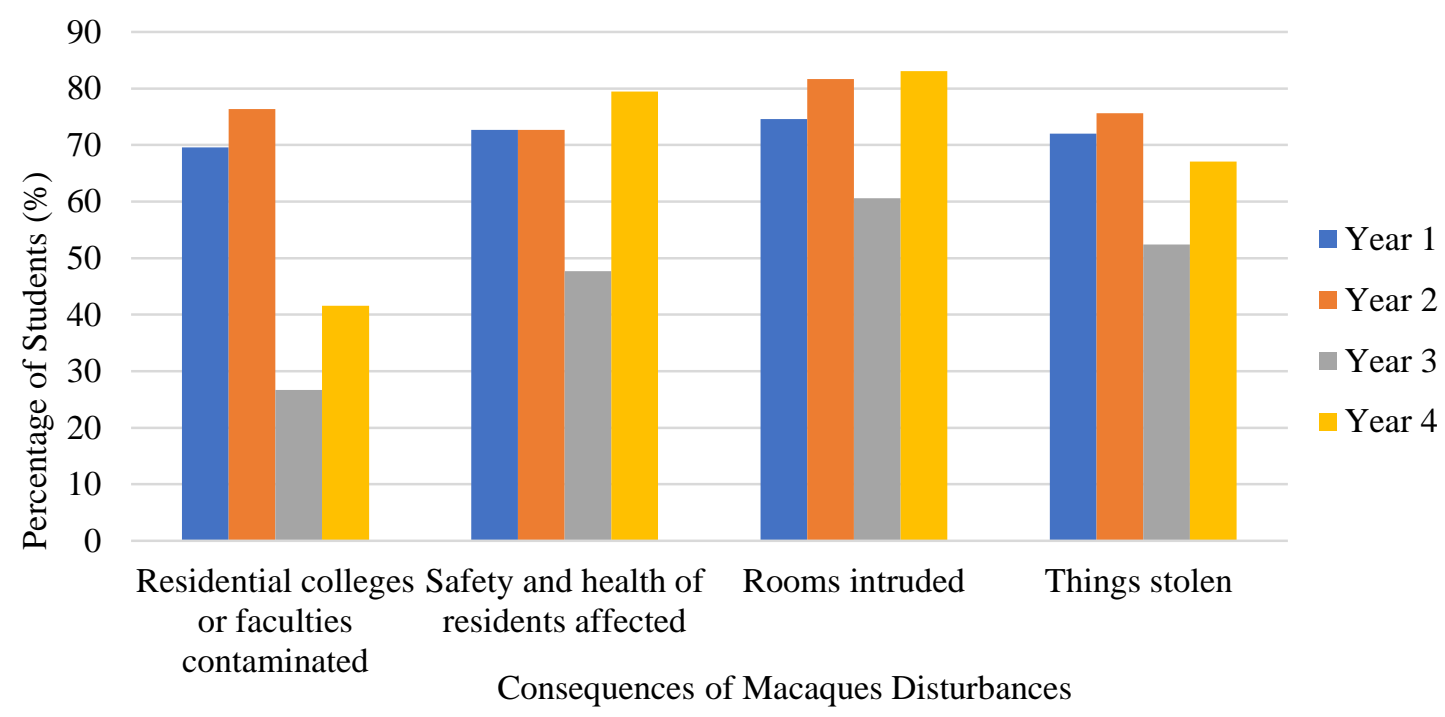

Figure 3. Percentage of students' perceptions and experiences of the consequences of macaque disturbances.

From these results, Year 3 students had the highest percentage of experiencing consequences of macaques entering their rooms and having things stolen by the primates. This matches the high percentage of Year 3 students who agreed on the undesirable consequences caused by macaques in contrast to the students of other academic years. The experiences of UM students being harassed by the monkeys maybe the reason why $70.0 \%$ from respective academic years believed the presence of macaques will affect the safety and health of residents. Macaque pest behaviours such as rummaging through trash and littering convinced students that their presence leads to contamination and other health hazards in the residential colleges and faculties.

\subsubsection{Category of Causal Factors of Macaque Disturbances}

A high percentage of students from respective academic years believed that searching for food or foraging was the main factor that had caused the macaques to enter the residential colleges and the faculties. More than $83.0 \%$ of students from different academic years agreed that a lack of natural food encouraged this pest behaviour and that the presence of food and drink stimulated aggressive macaque behaviour towards humans (Figure 4).

The percentages of Year 1 to Year 4 who selected 'searching for food' as the causal 
factor of macaques entering the residential colleges or the faculties were $83.2 \%, 84.1 \%$, $77.5 \%$ and $84.1 \%$, respectively. Following this factor was the belief in the lack of available natural foods for the animals, scoring: $44.7 \%$, $50.0 \%, 53.5 \%$ and $53.7 \%$ of students from each respective academic year. Alongside these factors, $47.8 \%$ of Year 1, 40.9\% of Year 2, 45.1\% of Year 3 and $52.4 \%$ of Year 4 students reported that the shrinking of natural habitat was another of the factors causing the macaques to impinge on the residential colleges or the faculties. Leftover food was the factor chosen by $49.7 \%, 40.9 \%, 43.7 \%$ and $47.6 \%$ of students from Year 1 to 4 , respectively, as encouraging the intrusion of macaques into both places.
Other possible factors which caused the intruding macaques suggested by the students were curiosity, nature, and habits of the macaques. They also believed that those areas were initially part of their natural habitat and activity areas, but had been converted and exploited for human use, causing the macaques to enter the residential colleges and faculties. Factors cited include macaque habitat being close to human habitat, open windows, and dustbins that were not covered. Instead it was actually a combination of their home range size reduction, poor waste management practices as well as habitat fragmentation due to the development of UM, formerly a forest, which was the contributing cause for the intrusion of the macaques.

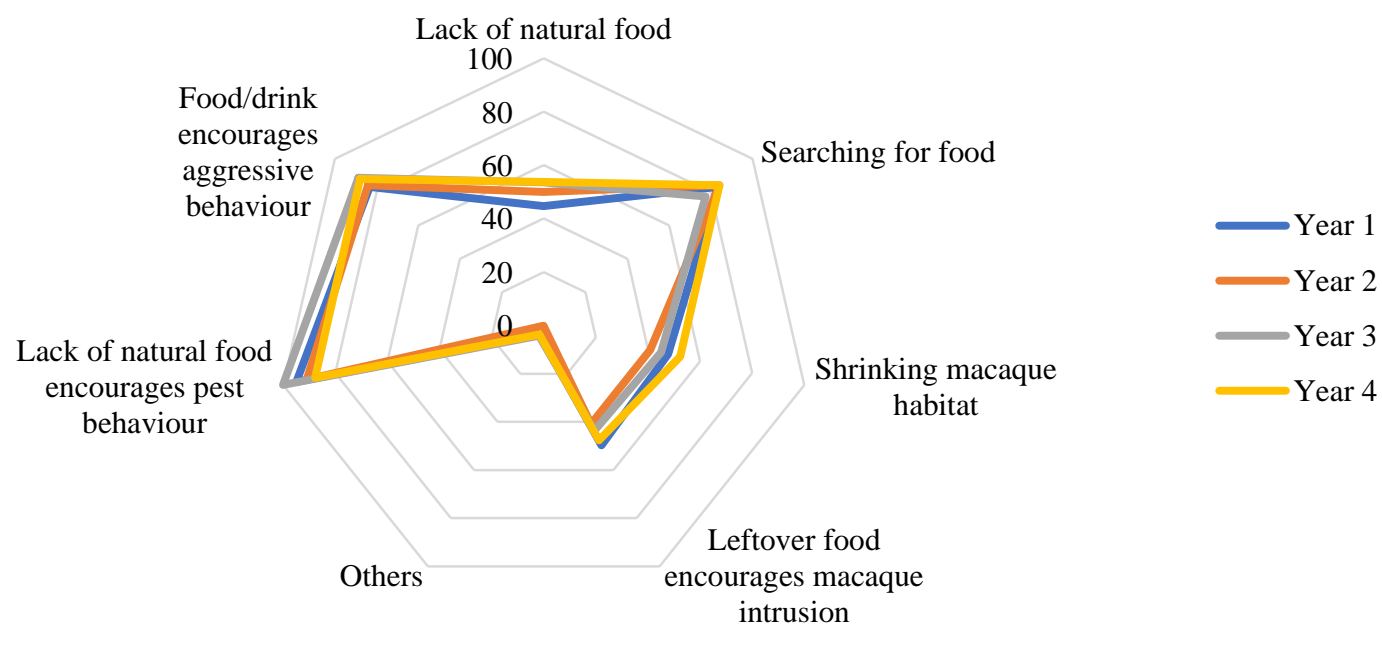

Figure 4. Percentage of students' perceptions on the causal factors of macaque disturbances.

Over $77.0 \%$ of students from Year 1 to Year 4 believed that the most important factor causing macaques to enter the residential colleges and the faculties was because of foraging. This can be explained by the experiences of all the students from Year 1 to Year 4 who lost their belongings, mostly food items (more than 94.0\%) to the macaques. More than $40.0 \%$ of students from each academic year believed that shrinking macaque habitat was the reason for macaque existence in the residential colleges or the faculties.
This reveals that the students were aware that urbanisation resulted in the shrinkage of wildlife habitat. More than $87.0 \%$ of students from all four academic years agreed that the lack of natural food encouraged the pest behaviour of macaques, such as rummaging trash bins and littering to search for food. However, these perceptions were in contrast to the findings of Sya and Hanya (2013b) where the main drivers for macaque exploitation of anthropogenic foods were unlikely to be natural food resources. 
Over $83.0 \%$ of Year 1 to Year 4 students thought that the presence of food or drink encourages aggressive behaviour by macaques. This perception can be supported by previous studies where macaques habituated to humans often exhibit undesirable behaviours associated with provisioning, including food snatching and human-directed aggression $(\mathrm{Fa}$, 1992; Fuentes \& Gamerl, 2005; Jones-Engel et al., 2011). The case study in Hong Kong also reported that macaque aggression towards humans somehow correlated with the possession of food. Due to frequent contacts with humans over the years, some macaques have become habituated to them. They have learned to snatch plastic bags from visitors because people who feed them usually carry plastic bags containing food, and sometimes macaque aggression has led to conflicts with local people (Jones-Engel et al., 2011).

\subsubsection{Category of Solutions to Overcome Problems caused by Macaques}

More than $85.0 \%$ of students from Year 1 to Year 4 reached a consensus that the authorities should take action to overcome the problem caused by macaques. A high percentage of students opted for translocating these animals, followed by putting nets on windows and providing caged and locked bins to solve the problems. The least favoured solution chosen by the students were shooting and poisoning the monkeys and cutting the trees near the residential colleges and the faculties (Figure 5).

The percentages of students from Year 1 to Year 4 who chose translocation to reduce the macaque disturbances were $78.3 \%, 63.6 \%$, $64.8 \%$ and $70.7 \%$, respectively. This was followed by $64.6 \%, 75.0 \%, 74.6 \%$ and $70.7 \%$ of students across the academic years that opted for putting nets on windows; $60.9 \%$ of Year 1 , $52.3 \%$ of Year 2, $64.8 \%$ of Year 3 and $78.0 \%$ of Year 4 students, preferred providing caged or locked bins to lessen the impact caused by the macaques.

Following this was a solution relevant to macaque translocation: the trap requests from the Department of Wildlife and National Parks was chosen by $47.2 \%$ of Year 1, 38.6\% of Year 2, 35.3\% of Year 3 and 35.4\% of Year 4 students. Less than $40 \%$ of students from all academic years believed that vasectomy will help to abate the impact of macaque disturbances. At the same time, the least favoured option - the inimical solution of poisoning or shooting the macaques - received not more than $5 \%$ of students approval from any academic year.

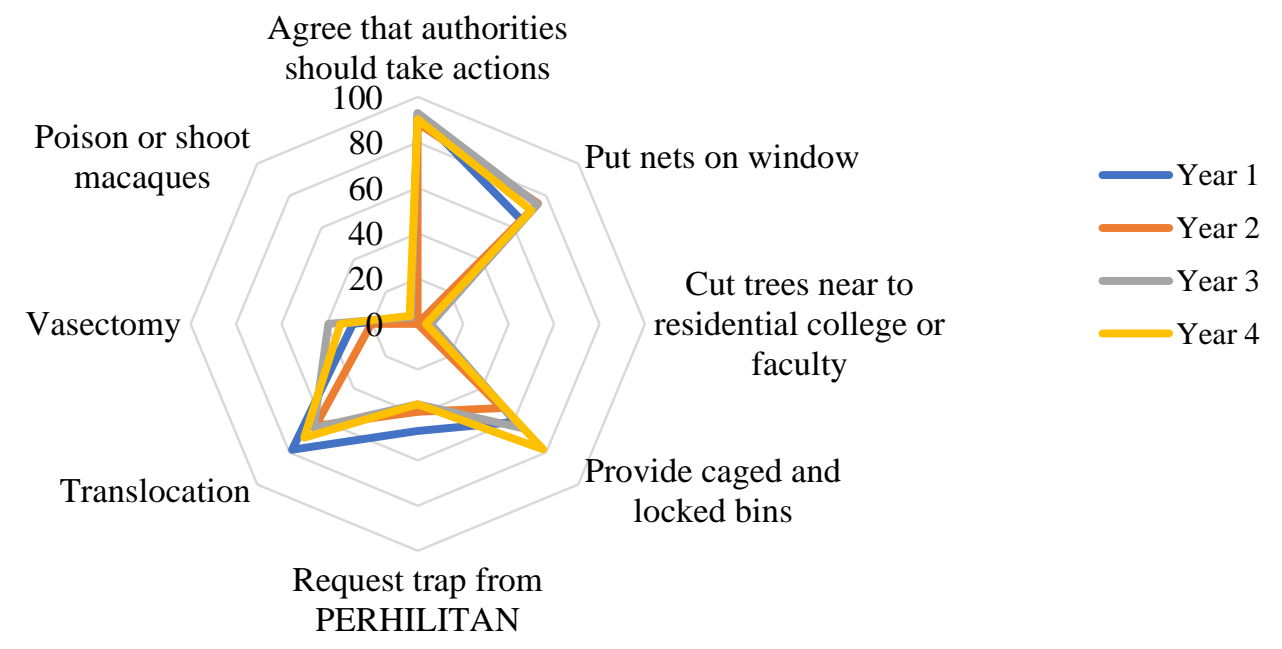

Figure 5. Percentage of students' perceptions on the solutions to overcome problems caused by macaques. 
There was an indication from the survey that the students were aware of animal welfare and conservation issues because most of them selected the options of translocation of macaques, putting nets on windows and providing caged and locked bins which they believe would be able to reduce the problems caused by macaques while the least selected 'cutting trees near residential colleges or faculties' and 'poisoning or shooting macaques'. Less than $40.0 \%$ of students from each respective academic year selected the option 'vasectomy would reduce the macaque nuisance'. However, vasectomy was reported to be effective to reduce the population of macaques at some locations (Shek \& Cheng, 2010), but this does not reduce the nuisances caused by the monkeys.

\subsection{Behaviours of Long-tailed Macaques in $\mathbf{U M}$}

\subsubsection{Activity Budgets of Long-tailed Macaques}

A total of 29 behavioural acts (Appendix B) by the macaques were observed and recorded during observations and they could be categorised into 11-behavioural activities for direct and clear interpretation. The activity budgets of low and high anthropogenic macaque groups are shown in Figure 6A and B. There was a significant difference between the sample medians of the macaque behaviours in UM (Kruskal Wallis test, $\mathrm{H}^{2}=372.3, \mathrm{df}=10$, $\left.\mathrm{p}=2.6 \times 10^{-75}\right)$, indicating the time allocated for each behaviour was not equal. The most frequently occurring behaviour for both macaque groups were locomotion, followed by vigilance and resting.

Based on Figure 6A, the low anthropogenic group spent most of their time engaged in locomotion (38.2\%), including the specific acts of walking, running, jumping, swinging and climbing, followed by vigilance $(21.6 \%)$ and resting $(13.5 \%)$. The category, social behaviour $(8.4 \%)$, shown by the low anthropogenic group was mostly affiliative actions like playing, mother-infant interactions, and lip smacking. Submissive behaviour came subsequently in response towards the aggressive behaviour of conspecifics or disturbances caused by humans or others. The percentage of occurrence of aggression behaviours like hitting, chasing, fighting and threatening of the low anthropogenic group was lower compared to other social behaviours. The low anthropogenic group foraged (6.6\%) mostly on trees but also spent a small proportion of their foraging time in human habitats. The acts of searching for food, eating, drinking and manipulating potential food objects were included in foraging or feeding behaviour. Vocalisation accounted for only $4.2 \%$, where the low anthropogenic group vocalised a lot when performing affiliative behaviours as well as when emitting alarm calls when they felt threatened by the presence of predators such as feral dogs. They spent some of their time in self-grooming (3.9\%) and allogrooming their conspecifics to maintain close bonds with each other due to their nature as social animals. The behaviour of staring $(1.4 \%)$ was mainly towards conspecifics and humans with or without head movement. The pest behaviours $(0.9 \%)$ of the low anthropogenic group were rummaging through trash or trash cans, littering, disturbing people and damaging facilities or properties. The act of rummaging through trash could occur simultaneously with the act of damaging properties, by which the macaque will push down the trash cans in order to easily access the trash or food waste inside. Sexual behaviour $(0.6 \%)$ shown by the low anthropogenic group included mating, self-directed sexual behaviour, such as playing with or examining their own genitals. During observations, the low anthropogenic group was sometimes out of sight $(0.7 \%)$.

Figure 6B shows that the high anthropogenic group was similar to the low anthropogenic group; spending most of their time in locomotion $(36.3 \%)$, vigilance $(24.9 \%)$ and resting $(12.3 \%)$. The percentage of foraging $(7.4 \%)$ for the high anthropogenic group was slightly higher than that of the low anthropogenic group, but social behaviour 
(6.4\%) was comparatively slightly lower. This was followed by grooming behaviour $(5.1 \%)$ and vocalisation $(2.2 \%)$. Pest behaviours (1.4\%) shown by the high anthropogenic group were similar to those of the low anthropogenic group. The acts of staring $(1.2 \%)$ or sexual behaviour (0.4) only occupied very small proportions of the overall activity budget. The percentage of time they were out of sight $(2.4 \%)$ was quite high for the high anthropogenic group because of their highly elevated areas of intense activity, such as the roof tops of buildings. This showed that the activity budgets of both groups were not significantly different from each other (Chi square test: $\left.\chi^{2}=4.07 ; \mathrm{df}=10 ; \mathrm{p}=0.85\right)$.

We found that neither of the macaque groups in UM showed abnormal behaviour and had high percentages of locomotion and lower percentages of resting, which indicated that they were both active and behaved normally. A high percentage $(21.6 \%$ - low anthropogenic group and $24.9 \%$ - high anthropogenic group) of vigilance behaviour may suggest that the macaques were conscious and alert about potential dangers when in the human dominated habitat.
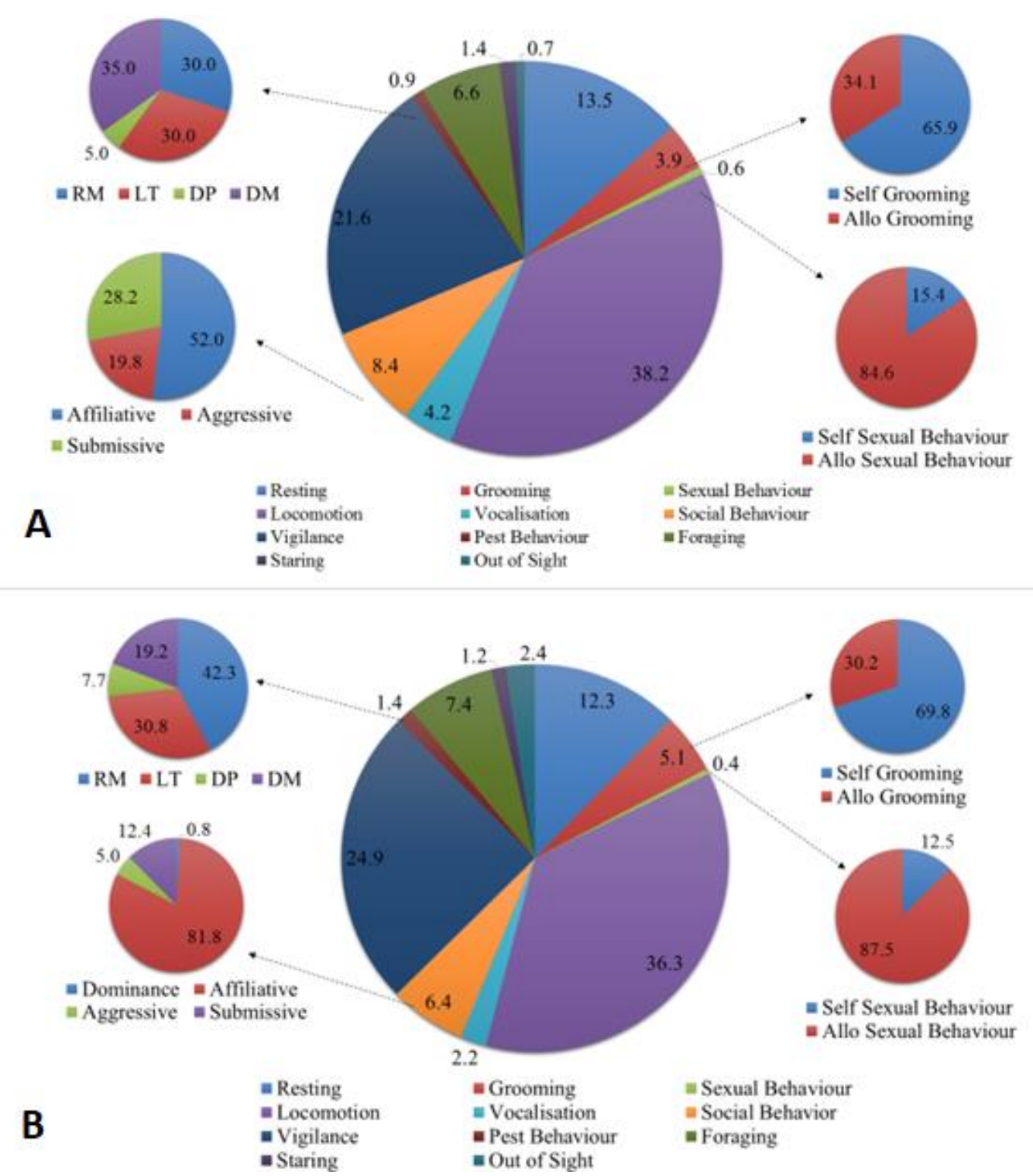

Figure 6. Activity budget for 11 behavioural acts for (A) low anthropogenic macaque group and

(B) high anthropogenic macaque group (\%).

$\mathrm{RM}=$ rummaging trash or trash can; $\mathrm{LT}=$ littering; $\mathrm{DP}=$ disturbing people;

$\mathrm{DM}=$ damaging facilities or properties 


\subsubsection{Pest Behaviour of Long-tailed Macaques}

The pest behaviours shown by both macaque groups in UM were rummaging trash or trash cans without covers and cans that were non-macaque proof. Littering also occurred after manipulating objects such as plastic bags when foraging, disturbing people such as approaching or following people and damaging facilities or properties such as pulling cables and wires, jumping on vehicles and roofs, playing car wipers and pushing down trash cans. Both the macaque groups in UM showed various pest behaviours. They rummaged through trash or trash cans without covers and those that were non-macaque proof. They also littered after manipulating objects such as plastic bags when they foraged for food. Besides, they disturbed people by approaching or following them. On top of that, they also damaged facilities or properties such as pulling cables and wires, jumping on vehicles and roofs, playing with car wipers and toppling trash cans.

From Figures 6A and $\mathrm{B}$ above, we found that the high anthropogenic group $(42.3 \%)$ had higher percentage of rummaging trash or trash can compared to the low anthropogenic group (30.0\%). Concurrently, we learned that the low anthropogenic group $(35.0 \%)$ exhibited a higher percentage of damaging facilities or properties than the high anthropogenic group (19.2\%). Both groups had similar percentage of littering and disturbing people. The percentage of littering and disturbing people for the low and the high anthropogenic groups were $30.0 \%, 30.8 \%$ and $5.0 \%, 7.7 \%$ respectively. However, the chi square test showed that the pest behaviour exhibited by both groups was not significantly different from each other $(\chi 2=7.05, \mathrm{df}=3$, $\mathrm{p}=0.07$ ).

In contrast to the high percentage of students experiencing negative impacts from the macaque behaviour, the pest behaviours of both macaque groups in UM were relatively low $(0.9 \%$ and $1.4 \%)$ in their activity budgets. Furthermore, both macaque groups showed low percentages $(5.0 \%$ and $7.7 \%)$ of disturbing people and none of the behaviour of breaking into rooms and stealing but relatively high percentage in their foraging behaviour such as rummaging through trash cans $(30.0 \%$ and $42.3 \%$ ) and littering (30.0\% and 30.8\%). Hence, we assumed that the students had experienced those negative impacts such as macaques having entered their room and getting their things stolen at different times such as morning or noon instead of evening since our observation was only done at 1630 to 1915 hours. This is because the active or feeding hour of macaques will mostly start from 0900 to 1000 hours, 1200 to 1300 hours as well as from 1400 to 1700 hours (Sussman \& Tattershall, 1981).

We found that the high anthropogenic group rummaged through trash cans or trash more than the low anthropogenic group and this may be due to the high preference to artificial food of the high anthropogenic group compared to the low anthropogenic group. The other possible reason may be due to the presence of a high number of uncovered or non-macaque proof trash cans in the area within the Faculty of Science. On the other hand, the higher number of juveniles in the low anthropogenic macaque group might be the factor that had caused the low anthropogenic group to have a higher percentage for damaging facilities or properties behaviour compared to the high anthropogenic group. The juvenile macaques were playful and always played with car wipers, wires and cables. They also jumped on the roof of the parking lot in the Faculty of Science Computer and Information Technology.

\subsection{Feeding Habits of Long-tailed Macaques (Low and High Anthropogenic Macaque Groups) in UM}

\subsubsection{Types of Food Eaten by Long-tailed Macaques}

The macaques in UM fed on nine species of plants from nine different families which included Polyalthia longifolia (Annonaceae), Mangifera indica 
(Anacardiaceae), Dypsis sp. (Arecaceae), Mesua ferrea (Calophyllaceae), Dillenia suffruticosa (Dilleniaceae), Acacia auriculiformis (Fabaceae), Ficus sp. (Moraceae), Vittaria sp. (Pteridaceae) and Glycosmis pentaphylla (Rutaceae). They consumed fruits, leaves and petioles of these plants in their natural food diet (Table 3). Besides, they also consumed different types of anthropogenic or artificial food obtained through their habit of scavenging in the waste dumps and trash cans or offered by humans. The examples of food obtained from scavenging were leftover fruits like green apples, mangoes and oranges, biscuits, bread, fried chicken, fish, 'karipap', 'kuih bakar', whipped potato, chips and chili sauce. They also acquired sweets, nuts and yellow noodles from human provision (Table 4).

Table 3. List of natural foods eaten by the low- and the high anthropogenic groups.

\begin{tabular}{|c|c|c|c|}
\hline \multicolumn{3}{|c|}{ Natural Food } & Macaque Group \\
\hline Family & Species & Part Eaten & \\
\hline Annonaceae & Polyalthia longifolia & Leaf & Low anthropogenic group \\
\hline Anacardiaceae & Mangifera indica & Fruit & \\
\hline Arecaceae & Dypsis sp. & Fruit & High anthropogenic group \\
\hline Calophyllaceae & Mesua ferrea & Petiole, Leaf & \\
\hline $\begin{array}{c}\text { Dilleniaceae } \\
\text { Fabaceae }\end{array}$ & $\begin{array}{c}\text { Dillenia suffruticosa } \\
\text { Acacia auriculiformis }\end{array}$ & $\begin{array}{l}\text { Fruit, Petiole } \\
\text { Fruit, Petiole }\end{array}$ & Low anthropogenic group \\
\hline $\begin{array}{c}\text { Moraceae } \\
\text { Pteridaceae }\end{array}$ & $\begin{array}{l}\text { Ficus sp. } \\
\text { Vittaria sp. }\end{array}$ & $\begin{array}{l}\text { Leaf } \\
\text { Leaf }\end{array}$ & High anthropogenic group \\
\hline Rutaceae & Glycosmis pentaphylla & Fruit, Petiole & Low anthropogenic group \\
\hline
\end{tabular}

From Table 3 above, the natural food eaten by the low anthropogenic group were fruits and petioles of $A$. auriculiformis, $D$. suffruticosa and $G$. pentaphylla as well as leaves of $P$. longifolia whereas the natural food eaten by the high anthropogenic group included petioles and leaves of $M$. ferrea, fruits of $M$. indica and Dypsis sp., along with leaves of Ficus and Vittaria sp..

Table 4. List of artificial food eaten by the macaques in UM.

\begin{tabular}{cc}
\hline & Artificial Food \\
\hline Type & Food Item \\
\hline Fruit & Green apples \\
& Mangoes \\
& Oranges \\
& Biscuits \\
Carbohydrate & Bread \\
& Yellow Noodles \\
Meat & Fried Chicken \\
& Fish \\
Grain & Nuts \\
& 'Karipap' \\
Dessert & 'Kuih Bakar' \\
& Whipped potato \\
Snack & Chips \\
& Sweets \\
Sauce & Chili sauce \\
\hline
\end{tabular}


The macaques' consumption of natural food was further divided into plant parts eaten and it was found that the low and the high anthropogenic macaque groups fed mostly on fruits, followed by petioles and leaves (Figure 7A and B).

From Figure 7A, it can be seen that the low anthropogenic group consumed mostly fruits $(50.7 \%)$. This was followed by petioles $(20.5 \%)$ and leaves $(6.8 \%)$. About $2.7 \%$ of the plant parts eaten by the macaques were unidentified, due to poor visibility in some cases.

From Figure 7B, it can be seen that the high anthropogenic group consumed similar amounts of fruits $(20.7 \%)$ and petioles $(20.7 \%)$, followed by leaves $(2.7 \%)$ as did the low anthropogenic group. Similarly, about $2.7 \%$ of plant parts eaten by this group of macaques could not be identified.

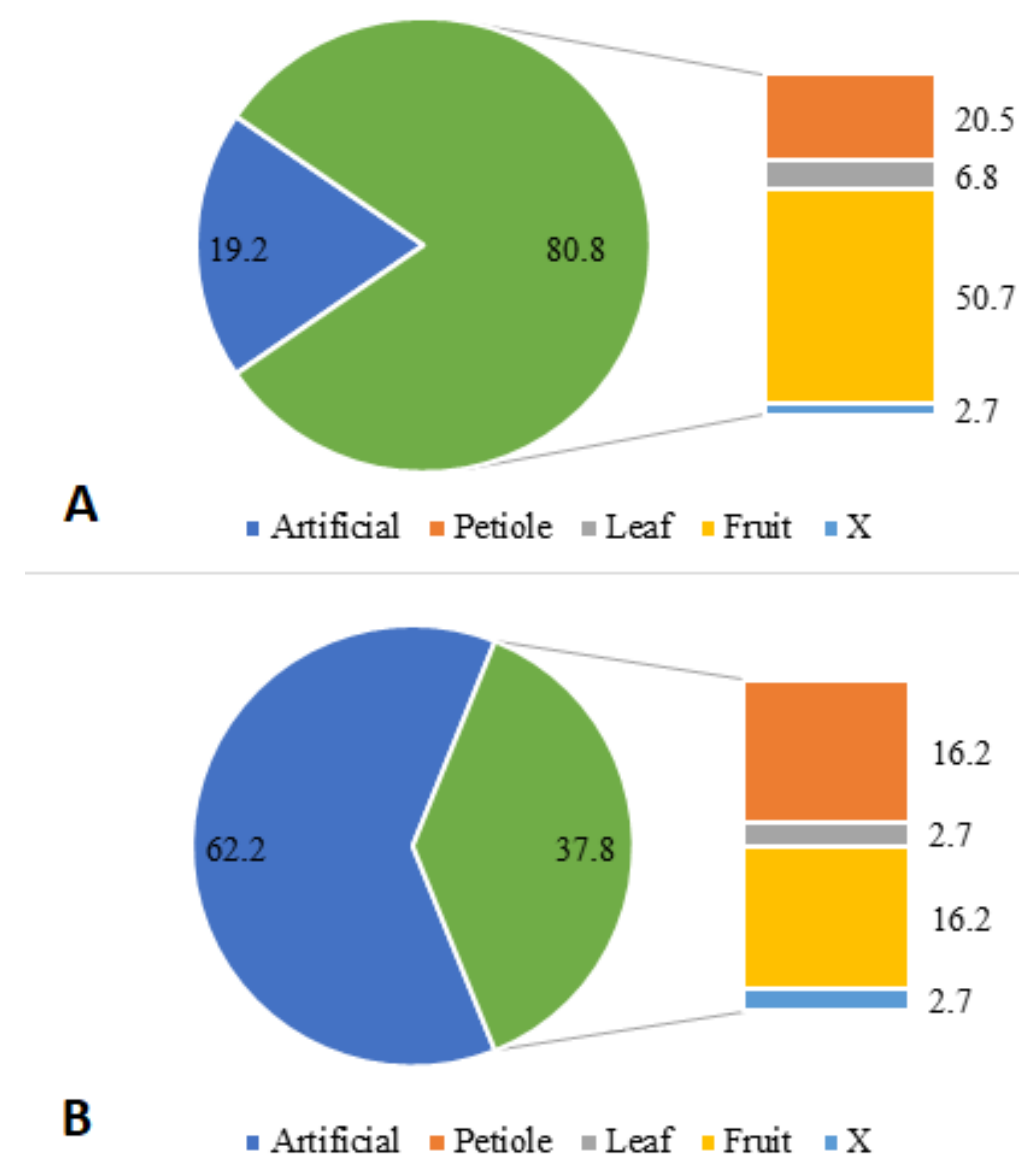

Figure 7. Percentage of plant parts of natural food eaten by the (A) low anthropogenic macaque group and (B) high anthropogenic macaque group.

(X= unknown)

M. indica and A. auriculiformis were the preferred natural food eaten by the macaques. These results are supported by Norma-Rashid \& Azarae (1992) from a study conducted at the same study site, by Hambali, et al. (2014) in the Kuala Selangor Nature Park (KSNP) and by Hadi et al. (2007) at the Chikakak Monkey Park, Indonesia.
In this study, we found that the macaques consumed fruits of $A$. auriculiformis, similar to that found by Norma-Rashid \& Azarae (1992), but this contrasted with the studies conducted at KSNP and the Chikakak Monkey Park where the macaques instead ingested the seeds of $A$. auriculiformis. 
We found that the plant parts of natural food consumed by both macaque groups were mainly fruits. This finding is supported by the observations of Berenstain (1986) and Yeager (1996), thus confirming the classification of long-tailed macaques as primarily being frugivorous.

\subsubsection{Comparison Between Diet of the Low and the High Anthropogenic Macaque Groups}

In this study, we also compared the proportions of different types of food eaten by both macaque groups. Figure 8 revealed a significant difference in the proportions of natural and artificial food consumed by the low anthropogenic group (Chi-squared test: $\left.\chi^{2}=38.63 ; \mathrm{df}=1 ; \mathrm{p}=5.12 \times 10^{-10}\right)$.

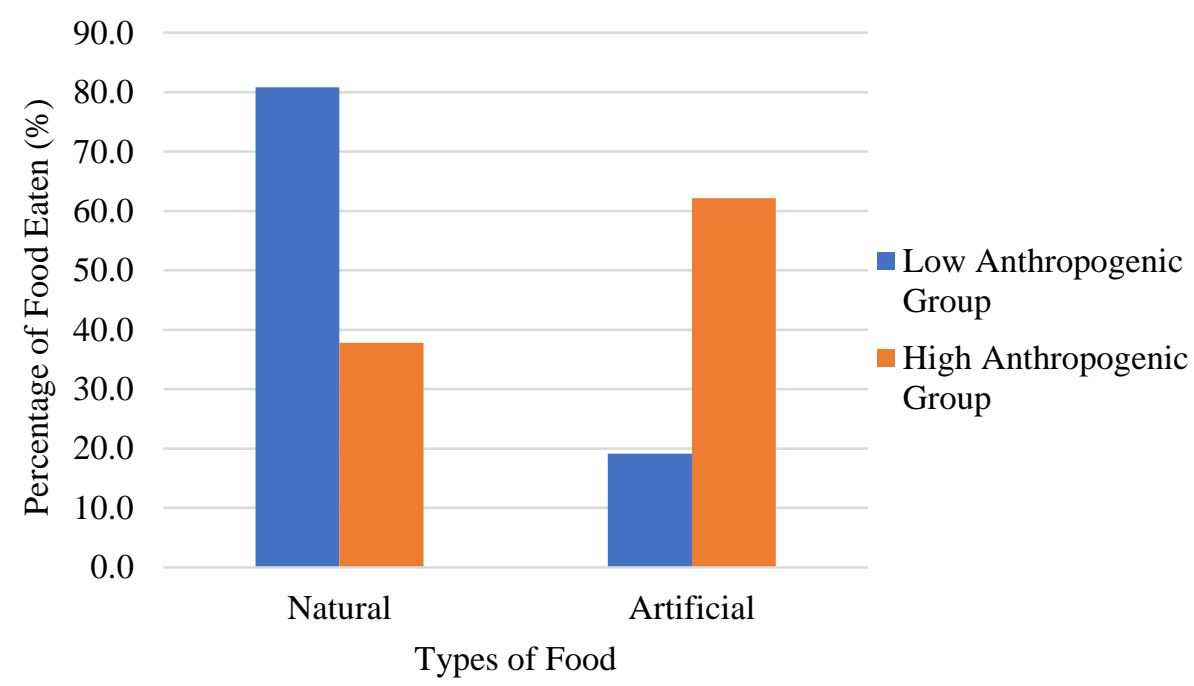

Figure 8. Comparison of food types eaten by the low- and the high anthropogenic macaque groups.

We found that the high anthropogenic group consumed more artificial food than natural food. This finding was similar to Sha and Hanya (2013a), showing that the longtailed macaques fed more on anthropogenic food and less on natural fruits and flowers. The high anthropogenic group also consumed more artificial food than the low anthropogenic group, and this can be reflected in the amount of pest behaviour displayed by the high anthropogenic group, where they rummaged through trash or trash cans more than the low anthropogenic group. Thus, anthropogenic food resources caused macaques to develop a dependence on high energy food and they consequently under-utilized natural food resources (Sha \& Hanya, 2013b).
The other possible factors at work here might be the different amount of time spent by the macaques in human and natural habitats. During observations, the low anthropogenic group spent more time in their natural habitat than in human habitat areas, while the reverse was true for the high anthropogenic group. The activity area of the low anthropogenic group was also closer to natural habitats, allowing them to forage more on natural foods while the high anthropogenic group carried out most of their activities inside the faculty premises and had limited opportunities to forage for more natural food.

Nevertheless, it might be due to the scarcity of natural food in the vicinity of the 
Faculty of Science because food enhancement (feeding on artificial food) facilitated the reduction of food stress (Fuentes, 2006), which explains why the high anthropogenic group fed more on artificial food. This is in strong contrast to the findings of Sha and Hanya (2013b), who reported higher feeding of anthropogenic food resources and not natural fruit resource scarcity. Thus, further study is needed to investigate on the natural food abundance in the UM campus to fill in gaps of information and their high dependence on artificial food.

Despite the fact that artificial food availability will reduce food stress faced by the macaques (Fuentes, 2006), it would, at the same time, increase the risk of aggressive behaviour among the macaques, creating different stress response patterns (Fuentes, 2006). The anthropogenic environments created by humans such as the waste dump due to poor waste management or practice and foods offered by humans resulted in a change of behaviour and increased aggressive interactions among the macaque troops.

Although waste dumps or food offered directly by humans provided ample food sources to the macaques, these animals needed to bear the risk of disease outbreaks due to potentially infected human foods. A study by Sapolsky and Share (2004) revealed that infected foods can change the demography of an olive baboon forest troop (Papio anubis) because the dominant baboons suffered and died from tuberculosis, contracted by their feeding on infected meat scavenged from waste dumps, which they had acquired preferential access to because of their dominance.

\subsection{Impact of Humans on Long-tailed Macaques (Low and High Anthropogenic Macaque Groups) in UM}

\subsubsection{Types of Disturbances on the Long- tailed Macaques}

The anthropogenic disturbances on the macaques included approaching or passing humans, being chased by humans with or without objects (stones or brooms), human noises and voices, approaching or passing vehicles, vehicle noises or honking and others such as noises from closing doors. The nonanthropogenic disturbances included the presence of dogs (Table 5). There was a significant difference in the kinds of disturbances faced by macaques in the low- and the high anthropogenic groups (Chi square test: $\left.\chi^{2}=58.65, \mathrm{df}=6, \mathrm{p}=8.45 \times 10^{-11}\right)$.

Table 5. List of disturbances on the low and the high anthropogenic macaque groups.

\begin{tabular}{|c|c|c|c|}
\hline \multicolumn{2}{|c|}{ Low Anthropogenic Group } & \multicolumn{2}{|c|}{ High Anthropogenic Group } \\
\hline \multicolumn{2}{|c|}{ Disturbances } & \multicolumn{2}{|c|}{ Disturbances } \\
\hline Human & Non-human & Human & Non-human \\
\hline $\begin{array}{l}\text { Approaching or } \\
\text { passing humans }\end{array}$ & \multirow{5}{*}{ Presence of dogs } & $\begin{array}{l}\text { Approaching or } \\
\text { passing humans }\end{array}$ & \\
\hline $\begin{array}{l}\text { Being chased by } \\
\text { humans with or } \\
\text { without tools }\end{array}$ & & $\begin{array}{l}\text { Being chased by } \\
\text { humans with or } \\
\text { without tools }\end{array}$ & \\
\hline $\begin{array}{l}\text { Approaching or } \\
\text { passing vehicles }\end{array}$ & & Human noises & \\
\hline $\begin{array}{c}\text { Noises or honking of } \\
\text { vehicles }\end{array}$ & & $\begin{array}{c}\text { Noises or honking of } \\
\text { vehicles }\end{array}$ & \\
\hline Others & & Others & \\
\hline
\end{tabular}


From Figure 9A and B, we found that the most frequent anthropogenic disturbances on both macaque groups were approaching or passing humans. We also found that human noises did not inflict the low anthropogenic group whereas approaching or passing vehicles and the presence of dogs were absent from the high anthropogenic group.

The low anthropogenic group that ranged in the vicinity of the Faculty of Science Computer and Information Technology experienced human and non-human disturbances (Figure 9A). The most frequently occurring disturbance was approaching or passing humans $(44.4 \%)$, whereby the macaques exhibited various submissive responses when students or staff approached or passed by the macaques in close proximity. This was followed by approaching or passing vehicles $(31.1 \%)$, such as cars and motorcycles when the macaques were active near the main road or parking area of the faculty. Humans chasing them (11.1\%) and vehicle noises $(8.9 \%)$ followed subsequently in occurrence and the least frequently occurring non-human disturbances were the presence of dogs $(2.2 \%)$ and others $(2.2 \%)$, such as noises caused by other animals, like tree shrews or squirrels (Tupaia glis) in bushes.

The high anthropogenic group ranging in the area of the Faculty of Science also experienced similar human and non-human disturbances as the low anthropogenic group (Figure 9B). The most frequently occurring disturbance was approaching or passing humans $(43.8 \%)$ followed by others $(18.8 \%)$, such as noises from closing doors. This was followed by humans chasing them with tools $(12.5 \%)$, human noises $(12.5 \%)$ and vehicles honking (12.5\%).

A
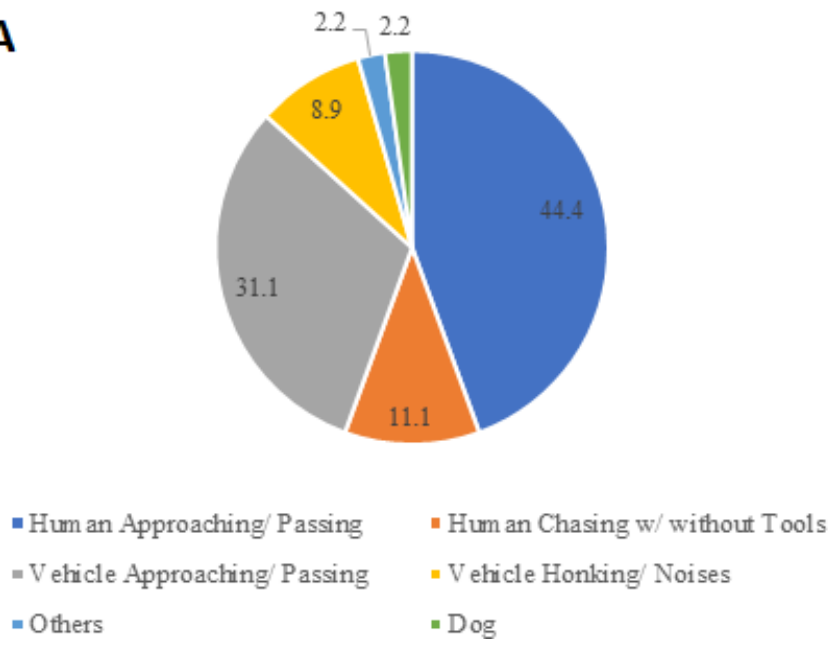

B
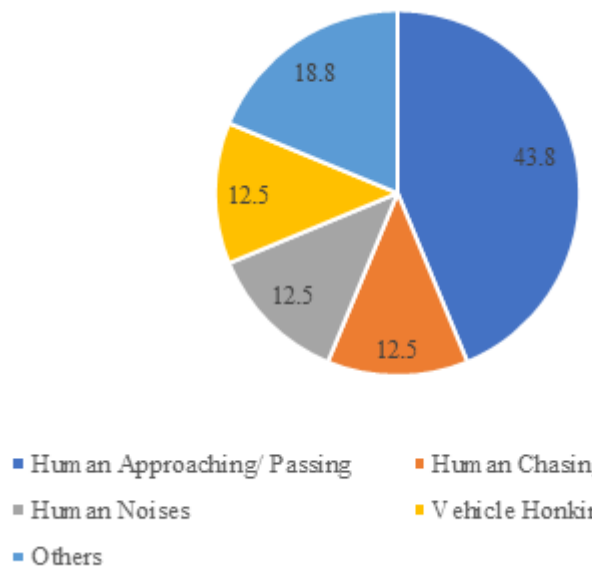

Figure 9. Percentage of disturbances faced by (A) low anthropogenic macaque group and (B) high anthropogenic macaque group. 
In this study, we found that the low anthropogenic group encountered high number of disturbances from approaching or passing humans and vehicles because the activity area of the macaques was immediately beside the main road. The disturbances that were faced by the high anthropogenic group were mainly approaching and passing humans but not vehicles because the activity area of the high anthropogenic group was in the area where buildings are and it was not close to the main road.

\subsection{Responses of Long-tailed Macaques towards Disturbances}

The responses of the low- and the high anthropogenic groups towards disturbances were recorded during observations. The use of response ranking for the macaques was adapted from the study of Lyon (2012). The responses of the macaques from the low and the high anthropogenic group were ranked on a scale of 1 to 5 based on the level of aggression from disruptive events and their resultant corresponding behaviours (Table 5). Low ranking responses of macaques towards various disturbance events included freezing and avoidance behaviours; mild responses which included fleeing or climbing up a tree, and large responses which included all troop members climbing up into the trees and giving alarm calls. From Figures 10Aand B, we found that the low anthropogenic group showed no or small to large responses towards human disturbances while the high anthropogenic group did not show large response, but only small to mild responses as well as no response to human disturbances.

Based on Figure 10A, the macaques of the low anthropogenic group showed a range of no response to mild responses towards disturbances in response to approaching humans and vehicles. The common or highest number of responses of macaques from the low anthropogenic group towards approaching humans was a mild response (40.0\%), such as fleeing and climbing up into trees, followed by no response $(35.0 \%)$ and small response $(25.0 \%)$. The macaques of this group showed no response $(35.7 \%)$, small responses $(14.3 \%)$ and mild responses (50.0\%) towards approaching or passing vehicles in front of or beside them. Macaques of the low anthropogenic group responded differently towards human chases, where some of them showed no response $(20.0 \%)$, a mild response $(60.0 \%)$ and even a large response $(20.0 \%)$, where all of the macaques climbed up the trees and alarm called when there were people throwing stones at them to chase them away. Also, this group gave small responses (25.0\%) or no response $(75.0 \%)$ towards the noises produced by vehicles such as engine dins or the honking of a horn.

Figure 10B shows the various responses given by the high anthropogenic group towards different types of disturbance events. The macaques from the high anthropogenic group showed no response $(42.9 \%)$, a small response $(14.3 \%)$ or a mild response $(42.9 \%)$ when humans approached or passed them. The macaques of this group showed behaviours such as fleeing and climbing up the trees, that were considered as mild responses when humans were chasing them using brooms and making noises simultaneously. The macaques exhibited mild responses such as fleeing when a group of staff were chatting and laughing in a group near them. They showed no response towards the noises caused by vehicles.

The macaques of the low anthropogenic group showed a large response when they spotted a feral dog coming towards them. The whole troop climbed up the trees and produced continuous alarm calls until the dog moved away. They showed small responses such as freezing and staying alert when they heard noises from tree shrews or squirrels in the bushes. 
We found that the high anthropogenic group displayed a neutral to moderate degree of fear towards human disturbances while the low anthropogenic group was neutral to moderate and showed a high degree of fear only towards humans chasing them with stones or in the presence of dogs. Both macaque groups showed a high percentage of vigilance behaviour and this could be because of the noise and human activity cycles which impacted them to a certain degree. However, the high level of habituation towards humans could explain why human danger did not override the needs of food in the high anthropogenic group.

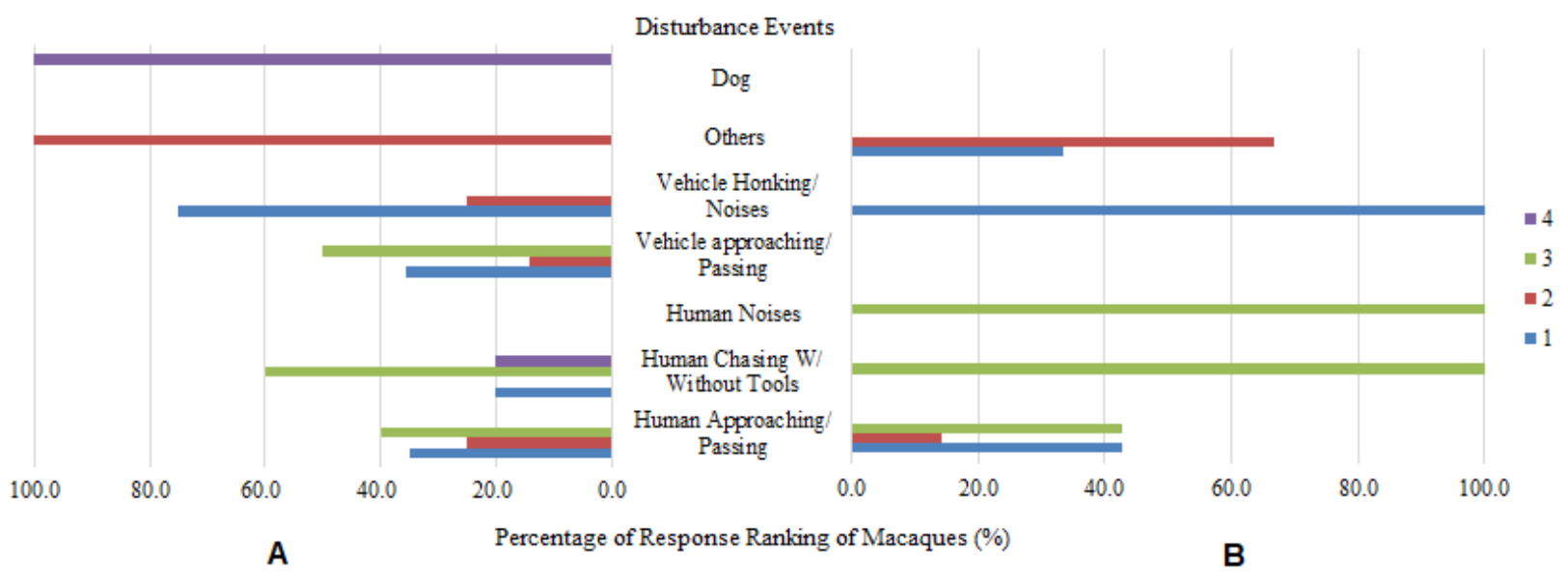

Figure 10. Percentage of response ranking of macaque groups (A) low anthropogenic macaque group and (B) high anthropogenic macaque group.

\section{CONCLUSION}

The presence of the long-tail macaques in UM had significant impacts on the students' daily lives. However, we should not only consider the impact on students when both humans and macaques share the same ecological and social space, but we should also look at the matter in a more comprehensive way and consider the impacts caused by humans on the macaques too.

From this study, we were able to observe different types and levels of humanmacaque interactions. We managed to study the students' perceptions, as they are part of the coexistence of human beings and macaques, by administering a questionnaire survey that had elicited their suggestions on how to solve the perceived problems. Additionally, in this study we were also concerned about the macaques' welfare, since the area was initially their natural habitat. We did this by studying their feeding habits and the level of human disturbances on them. Observable impacts were found for both macaques and humans. The impacts caused by the macaques were mostly due to their foraging behaviour that comprised the act of rummaging through trash or trash cans, physical disturbances towards humans such as threatening and chasing people, as well as the act of stealing food and other items from them.

Instead of depending on only one type of food, different macaque groups in UM had different preferences for natural and artificial food. The feeding habits of the macaques in UM can be considered as normal based on their natural food diet which mostly consisted of fruit that matched their frugivorous nature. However, due to the intensive contact with humans and their anthropogenic environment, such as accessible waste dumps due to poor waste management, some of the macaques in UM had shifted their diet to be more dependent on artificial food. 
Even though the impact caused by humans on macaques was not severe, we cannot deny that the anthropogenic habitat disturbances initiated by humans have resulted in irreversible changes to the macaque behaviour, especially their feeding habits. Yeager (1996) has reported that in the secondary forest of Kalimantan, the macaques that have no contact with humans are fully dependent on natural resources. However, due to urbanisation which has created large amounts of forest edges, the macaques have started to change their feeding habits from being primarily frugivorous to being highly omnivorous.

Not only considering the needs of humans, the welfare of wildlife such as the macaques should also be taken into account when planning or executing any actions to alleviate the conflicts arising from humanmacaque coexistence because of the 2-way impacts. Amelioration of human-macaque conflicts can be done by creating landscapes or infrastructures that minimise the overlap of humans and macaques, such as placing macaque proof nets or small inter-spaced window bars on domiciles, effective waste management through the instalment of macaque proof bins (this was also suggested by the students who took part in the survey), conducting public awareness campaigns to encourage appropriate human behaviour when encountering macaques, and creating buffer or feeding zones at particular locations within the campus. Even though we are not able to reverse the macaques to their natural behaviour or restore the habitat to its original state, we should try our best to conserve and sustain macaque populations because they have rights to live a better life.

\section{ACKNOWLEDGEMENTS}

I would like to express my gratitude to Prof. Dr. Norma Yusoff, Madam Mok Mee
Yoke and ISB staff for their guidance and assistance throughout the study.

\section{REFERENCES}

Altmann, J. (1974). Observational study of behaviour: sampling methods. Behaviour 49(3-4): 227-266, DOI: $10.1163 / 156853974 X 00534$

Altmann, J. and Muruthi, P. (1988). Differences in daily life between semiprovisioned and wild- feeding baboons. American Journal of Primatology 15: 213-221, DOI:10.1002/ajp.1350150304

Anuar, S. (2011). Social Organization and Mating System of MacacaFascicularis (Long Tailed Macaques). International Journal of Biology 3(2): 23-31, DOI: 10.5539/ijb.v3n2p23

Aureli, F. (1992). Post-conflict behaviour among wild long-tailed macaques (Macacafascicularis). Behavioral Ecology and Sociobiology 31(5): 329337, DOI: 10.1007/BF00177773

Berenstain, L. (1986). Responses of LongTailed Macaques to Drought and Fire in Eastern Borneo: A Preliminary Report. Biotropica1 8(3): 257-262, DOI: $10.2307 / 2388494$

Brent, L., \&Veira, Y. (2002). Social Behavior of Captive Indochinese and Insular Long- Tailed Macaques (Macacafascicularis) Following Transfer to a New Facility. International Journal of Primatology, 23(1), 147-159, DOI: 10.1023/A:1013206125884

de Ruiter, J.R.,van Hooff, J.A.R.A.M.\& Scheffrahn, W. (1994). Social and 
Genetic Aspects of Paternity in Wild Long-Tailed Macaques (Macaca fascicularis). Behaviou, 129(3-4): 203224, DOI: $10.1163 / 156853994 X 00613$

Fa, J. E. (1992), Visitor- directed aggression among the Gibraltar macaques. Zoo Biology 11(1): 43-52, DOI: 10.1002/zoo.1430110106

Fooden, J. (1995). Systematics review of Southeast Asian longtail macaques, Macaca fascicularis (Raffles, 1821). Fieldiana Zoology New Series 81: 2-3.

Fuentes, A. (2006). Human-nonhuman primate interconnections and their relevance to anthropology. Ecological and Environmental Anthropology (University of Georgia) 2(2): 1-11

Fuentes, A. (2007). Monkey and Human Interconnections: The Wild, the Captive, and the In-between. In R. Cassidy \& M. Mullin (Eds.). Where the Wild Things Are Now: Domestication Reconsidered (pp. 123-146). London: Bloomsbury Academic. DOI: 10.5040/9781474215954.ch-005

Fuentes, A. (2012). Ethnoprimatology and the anthropology of the human-primate interface. Annual Review of Anthropology 41: 101-117, DOI: 10.1146/annurev-anthro-092611145808

Fuentes, A. and Hockings, K. J. (2010), The ethnoprimatological approach in primatology. American Journal of Primatology 72: 841-847, DOI:10.1002/ajp.20844

Fuentes, A., \&Gamerl, S. (2005). Disproportionate participation by age/sex classes in aggressive interactions between long-tailed macaques (Macacafascicularis) and human tourists at Padangtegal monkey forest, Bali, Indonesia. American Journal of Primatology 66(2): 197-204, DOI: 10.1002/ajp.20138

Fuentes, A., Rompis, A., Arta Putra, I., Watiniasih, N., Suartha, I., Soma, I., Selamet, W. (2011). Macaque behavior at the human-monkey interface: The activity and demography of semi-freeranging Macaca fascicularis at Padangtegal, Bali, Indonesia. In A. Fuentes (Author) \& M. Gumert \& L. Jones-Engel (Eds.), Monkeys on the Edge: Ecology and Management of Long-Tailed Macaques and their Interface with Humans (Cambridge Studies in Biological and Evolutionary Anthropology, pp. 159-182). Cambridge: Cambridge University Press, DOI: 10.1017/CBO9780511974434.008

Gumert, M. D. (2007). Grooming and Infant Handling Interchange in Macaca fascicularis: The Relationship Between Infant Supply and Grooming Payment. International Journal of Primatology 28(5): $\quad$ 1059-1074, DOI: 10.1007/s10764-007-9202-0

Gumert, M. (2011). The common monkey of Southeast Asia: Long-tailed macaque populations, ethnophoresy, and their occurrence in human environments. In A. Fuentes (Author) \& M. Gumert\& L. Jones-Engel (Eds.), Monkeys on the Edge: Ecology and Management of Long-Tailed Macaques and their Interface with Humans (Cambridge Studies in Biological and Evolutionary Anthropology, pp. 3-44). Cambridge: Cambridge University Press. DOI: 10.1017/CBO9780511974434.003

Hadi, I., Suryobroto, B., \& PerwitasariFarajallah, D. (2007). Food preference of semi-provisioned macaques based on feeding duration and foraging party size. HAYATI Journal of Biosciences 14(1): 13-17, DOI: 10.4308/hjb.14.1.13 
Hambali, K., Ismail, A., \& Md-Zain, B. M. (2012). Daily activity budget of longtailed macaques (Macaca fascicularis) in Kuala Selangor Nature Park. International Journal of Basic \& Applied Sciences 12(4): 47-52.

Hambali, K., Ismail, A., Zulklifi, S. Z., MdZain, B. M., \& Amir, A. (2012). Human-macaque conflict and pest behaviors of long-tailed macaques (Macaca fascicularis) in Kuala Selangor Nature Park. Tropical Natural History12 (2): 189-205.

Hambali, K., Ismail, A., Md-Zain, B. M., Amir, A., \& Karim, F. A. (2014). Diet of Long-Tailed Macaques (Macaca fascicularis) at the entrance of Kuala Selangor Nature Park (Anthropogenic Habitat): Food selection that leads to human-macaque conflict. Acta Biologica Malaysiana, 3(2): 58-68, DOI: 10.7593/abm/3.2.58

Hanya, G., Noma, N., \& Agetsuma, N. (2003). Altitudinal and seasonal variations in the diet of Japanese macaques in Yakushima. Primates 44(1): 51-59, DOI: $10.1007 / \mathrm{s} 10329-002-0007-7$

Jones-Engel, L., Engel, G., Gumert, M., \& Fuentes, A. (2011). Developing sustainable human-macaque communities. In A. Fuentes (Author) \& M. Gumert \& L. Jones-Engel (Eds.), Monkeys on the Edge: Ecology and Management of Long-Tailed Macaques and their Interface with Humans (Cambridge Studies in Biological and Evolutionary Anthropology, pp. 295-327). Cambridge: Cambridge University Press, DOI: 10.1017/CBO9780511974434.014

Kassim, N., Hambali, K., \& Amir, A. (2017). Nutritional Composition of Fruits Selected by Long-Tailed Macaques (Macaca fascicularis) in Kuala
Selangor, Malaysia. Tropical life sciences research 28(1): 91-101, DOI:10.21315/tlsr2017.28.1.6

Lyon, J. R. A. (2012). The'anatomy of Disturbance': A Study of Anthropic Disturbance on Barbary Macaque (Macaca Sylvanus) Troops in the Middle Atlas, Morocco. Department of Life Sciences, Silwood Park, Imperial College London.

Malaivijitnond, S., \& Hamada, Y. (2008). Current situation and status of longtailed macaques (Macaca fascicularis) in Thailand. Tropical Natural History 8(2): 185-204.

Malaivijitnond, S., Vazquez, Y., \& Hamada, Y. (2011). Human impact on long-tailed macaques in Thailand. In A. Fuentes (Author) \& M. Gumert \& L. JonesEngel (Eds.), Monkeys on the Edge: Ecology and Management of LongTailed Macaques and their Interface with Humans (Cambridge Studies in Biological and Evolutionary Anthropology, pp. 118-158). Cambridge: Cambridge University Press, DOI:10.1017/CBO9780511974434.00 7

McKinney, T. (2015), A classification system for describing anthropogenic influence on nonhuman primate populations. American Journal of Primatology 77: 715-726, DOI: 10.1002/ajp.22395

Md-Zain, B. M., Sha'ari, N. A., Mohd-Zaki, M., Ruslin, F., Idris, N. I., Kadderi, M. D., \& Idris, W. M. R. (2010). A comprehensive population survey and daily activity budget on long-tailed macaques of Universiti Kebangsaan Malaysia. Journal of Biological Sciences 10(7): 608-615.

Md-Zain, B. M., Ruslin, F., \& Idris, W. M. R. (2014). Human-Macaque Conflict at the 
Main Campus of Universiti Kebangsaan Malaysia. Pertanika Journal of Tropical Agricultural Science 37(1): 73-85.

Nijman, V., \& Nekaris, K. A. I. (2010). Testing a model for predicting primate cropraiding using crop-and farm-specific risk values. Applied Animal Behaviour Science 127(3-4): 125-129, DOI: 10.1016/j.applanim.2010.08.009

Nila, S., Suryobroto, B., \& Widayati, K. A. (2014). Dietary Variation of Long Tailed Macaques (Macaca fascicularis) in Telaga Warna, Bogor, West Java. HAYATI Journal of Biosciences 21(1): 8-14, DOI: 10.4308/hjb.21.1.8

Norma-Rashid, Y., \&Azarae, H. (1992). Feeding and home range studies of the long-tailed macaques (Macaca fascicularis) inhabiting forest fragments in the campus of the University of Malaya. Simposium Sumber Alam Kebangsaan Pertama FSSA UKM Kampus Sabah, pp. 249258.

Priston, N.E.C. \& McLennan M.R. (2013) Managing Humans, Managing Macaques: Human-Macaque Conflict in Asia and Africa. In: Radhakrishna S., Huffman M., Sinha A. (eds) The Macaque Connection. Developments in Primatology: Progress and Prospects, 43. New York, NY, DOI: 10.1007/9781-4614-3967-7_14

Riley, E. P. (2007). The human-macaque interface: conservation implications of current and future overlap and conflict in Lore Lindu National Park, Sulawesi, Indonesia. American Anthropologist New Series 109(3): 473-484.

Riley, E. P., \& Fuentes, A. (2011). Conserving social-ecological systems in Indonesia: Human- nonhuman primate interconnections in Bali and Sulawesi.
American Journal of Primatology 73(1): 62-74, DOI: 10.1002/ajp.20834

San, A. M., \& Hamada, Y. (2009). Reproductive seasonality of Myanmar long-tailed macaque (Macaca fascicularis aurea). Tropical Natural History 9(2): 223-234.

Sha, J. C., Gumert, M. D., Lee, B. P., JonesEngel, L., Chan, S., \& Fuentes, A. (2009). Macaque-human interactions and the societal perceptions of macaques in Singapore. American journal of primatology, 71(10): 825839, DOI:10.1002/ajp.20710

Sha, J. C. M \& Hanya, G. (2013a), Diet, Activity, Habitat Use, and Ranging of Two Neighboring Groups of FoodEnhanced Long- Tailed Macaques (Macaca fascicularis). American Journal of Primatology 75(6): 581-592, DOI:10.1002/ajp.22137

Sha, J. C. M., \& Hanya, G. (2013b). Temporal food resource correlates to the behavior and ecology of food-enhanced longtailed macaques (Macaca fascicularis). Mammal Study 38(3): 163-175.

Shek, C.T. \& Cheng, W.W. (2010). Population survey and contraceptive neutering programme of macaques in Hong Kong. Hong Kong Biodiversity 19: 4-7.

Son, V. D. (2003). Diet of Macaca fascicularis in a mangrove forest, Vietnam. Laboratory primate newsletter 42(4): 1-5.

Sussman, R. W., \& Tattersall, I. (1981). Behavior and ecology of Macaca fascicularis in Mauritius: A preliminary study. Primates 22(2):192-205, DOI: 10.1007/BF02382610

Sussman, R. W., \& Tattersall, I. (1986). Distribution, abundance, and putative ecological strategy of Macaca 
fascicularis on the island of Mauritius, southwestern Indian Ocean. Folia Primatologica 46(1): 28-43, DOI: $10.1159 / 000156234$

Ungar, P. S. (1994). Patterns of ingestive behavior and anterior tooth use differences in sympatric anthropoid primates. American Journal of Physical Anthropology 95(2): 197-219, DOI: 10.1002/ajpa.1330950207

Wenz-Muecke, A., Sithithaworn, P., Petney, T. N., \& Taraschewski, H. (2013). Human contact influences the foraging behaviour and parasite community in long-tailed macaques. Parasitology
140(6):
709-718,
DOI:
10.1017/S003118201200203X

Wheatley, B. P. (1980). Feeding and ranging of East Bornean Macaca fascicularis. In Linburg, D. (ed.), The Macaques: Studies in Ecology, Behavior and Evolution, Van Nostrand Reinhold: New York, pp. 215-246.

Yeager, C. P. (1996). Feeding ecology of the long-tailed macaque (Macaca fascicularis) in Kalimantan Tengah, Indonesia. International Journal of Primatology 17(1): 51-62, DOI: 10.1007/BF02696158 


\section{Appendix A}
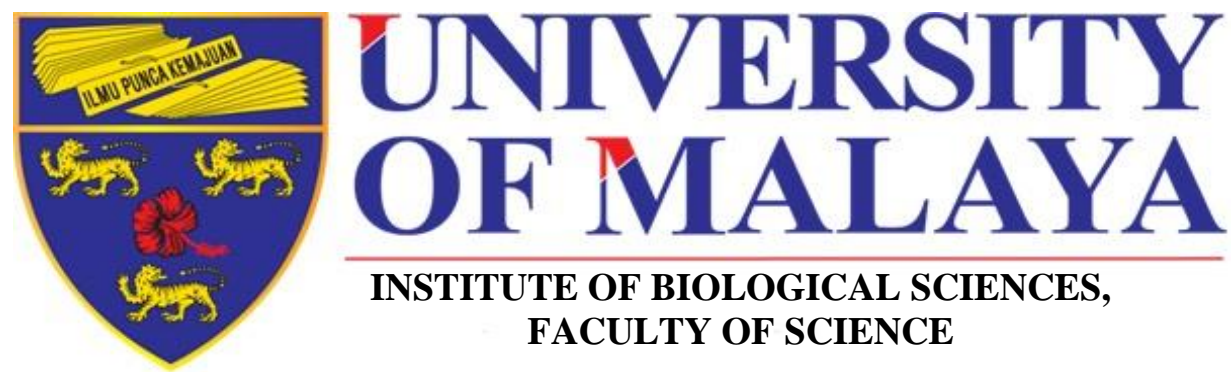

INSTITUTE OF BIOLOGICAL SCIENCES, FACULTY OF SCIENCE

This questionnaire survey is intended to identify the problems of macaque (monkey) disturbance in University of Malaya area. Questionnaire is adapted from HAMBALI, K., ISMAIL, A., ZULKIFLI, S. Z., MD-ZAIN, B. M., \& AMIR, A. (2012). Human-macaque conflict and pest behavior of longtailed macaques (Macaca fascicularis) in Kuala Selangor Nature Park. Tropical Natural History, 12(2), 189-205.

\section{PART A (Respondent Information)}

1. Gender: (a) Male $\quad$ (b) Female

2. Faculty:

3. Residential College:

4. Year: $1 / 2 / 3 / 4$

\section{Part B (Macaque Disturbances)}

5. Are you afraid of macaque?
A. Yes
B. No

6. Have you been disturbed, chased or bitten by macaque?
A. Yes
B. No
Circle your answer - Disturbed / Chased / Bitten

7. Have you ever seen other people being disturbed by macaque?
A. Yes
B. No

8. Have you ever seen the macaques roamed in your residential college or faculty?
A. Yes
B. No
Circle your answer - Residential college / Faculty / Both

\section{Part C (Consequences of Macaque Disturbances)}

9. Does the existence of macaque contaminate your residential college/ faculty?
A. Yes
B. No

10. Do you feel the existence of macaque affects the safety and health of the residents?
A. Yes
B. No

11. Have the macaques entered to your room?
A. Yes
B. No 
12. Have the macaques stole or took anything from your room?
A. Yes
B. No

13. What type of thing that macaque stole or took from you?
A. Food
B. Drink
C. Others, please state:

\section{Part D (Causal Factors)}

14. What is the possible reason that causes macaque entering your residential college/ faculty? (Answer can be more than one)
A. Lack of natural food
B. Searching for food
C. Shrinking macaque habitat
D. Leftover food encourages intrusion of macaque
E. Other, please state:

15. Do you think that lack of natural food encourages pest behaviour of macaque? (etc. messing up trash can, littering...)
A. Yes
B. No

16. Do you think that presence of food/drink encourages aggressive behaviour of macaque towards human? (etc. chasing, biting people)
A. Yes
B. No

\section{Part E (Suggestions to Overcome Problems)}

17. Do you agree that the authorities need to take some actions to reduce this disturbance?
A. Yes
B. No

18. Which steps that you agree should be taken by the authorities to overcome this problem?
A. Put nets on windows
B. Cutting trees near your house
C. Provide bins that cannot be opened by macaque (caged with lock)
D. Request traps from PERHILITAN to put at house area

19. Does the macaque need to be caught and transferred (translocation) to another place to reduce disturbance?
A. Yes
B. No
(Translocation: capture and then releases the animals from one habitat to another)

20. Do the male macaques need to be sterile (vasectomy) to reduce the population of the macaque and indirectly reduce the disturbance?
A. Yes
B. No
(Vasectomy: surgical procedure designed to make the male monkeys sterile to prevent pregnancy)

21. In your opinion, does the macaque need to be poisoned or be shot to reduce the disturbance?
A. Yes
B. No 


\section{Appendix B}

\begin{tabular}{|c|c|c|}
\hline Behaviour & Code & Description \\
\hline \multicolumn{3}{|c|}{ General \& Non-social } \\
\hline Locomotion & $\mathrm{L}$ & Focus animal is walking, running, jumping, etc. \\
\hline Resting & I & $\begin{array}{l}\text { Focus animal is not asleep but not engaging in other } \\
\text { behaviours. }\end{array}$ \\
\hline Vigilance & V & $\begin{array}{l}\text { Focus animal is looking up, down, to the side, with or } \\
\text { without head movement as well as body movement such } \\
\text { as standing. }\end{array}$ \\
\hline Foraging/Feeding & $\mathrm{F}$ & Focal animal is looking for food, eating or drinking. \\
\hline Auto grooming & SG & $\begin{array}{l}\text { Focus animal is grooming e.g.: cleaning its fur or picks } \\
\text { through the hair using fingers or mouth. }\end{array}$ \\
\hline $\begin{array}{c}\text { Self-directed } \\
\text { Sexual Behaviour }\end{array}$ & SS & Focus animal is playing or inspecting own genital. \\
\hline Staring & ST & $\begin{array}{l}\text { Focus animal is looking constantly at any object, } \\
\text { conspecific or human. }\end{array}$ \\
\hline Vocalisation & $\mathrm{VC}$ & $\begin{array}{l}\text { Focus animal is producing low/ high or short/long } \\
\text { sounds. }\end{array}$ \\
\hline \multicolumn{3}{|r|}{ Social } \\
\hline Branch-shaking & $\mathrm{BS}$ & Focus animal is shaking tree branch. \\
\hline \multicolumn{3}{|r|}{ Affiliative } \\
\hline Allogrooming & G & $\begin{array}{l}\text { Focus animal is cleaning the others' furs or picks } \\
\text { through the hair of another using fingers or mouth. }\end{array}$ \\
\hline Hugging & $\mathrm{H}$ & $\begin{array}{l}\text { Focus animal is squeezing or embracing others in its } \\
\text { arms. }\end{array}$ \\
\hline Playing & $\mathrm{P}$ & $\begin{array}{l}\text { Focus animal is engaging in activity for enjoyment with } \\
\text { others. }\end{array}$ \\
\hline Mother-infant interaction & MI & $\begin{array}{l}\text { Focus animal, which may be the mother or another } \\
\text { individual, inspecting, playing with, grooming, nursing, } \\
\text { hugging etc. an infant. }\end{array}$ \\
\hline Sexual Behaviour & SB & Mating, elicitation, mounting, etc. \\
\hline Lip Smack & LS & $\begin{array}{l}\text { Rapid lip movements, with or without tongue, directed } \\
\text { towards a conspecific or a person. }\end{array}$ \\
\hline \multicolumn{3}{|r|}{ Aggressive } \\
\hline Hitting & HT & Focus animal is hitting others by using limb. \\
\hline Chasing & $\mathrm{CH}$ & Focus animal is chasing a fixed target (conspecific). \\
\hline Fighting & FT & Focus animal is fighting with others. \\
\hline Threaten & $\mathrm{T}$ & $\begin{array}{l}\text { Focus animal is threatening the other by open mouth, } \\
\text { stand or vocalise. }\end{array}$ \\
\hline \multicolumn{3}{|r|}{ Submissive } \\
\hline Look away & LA & $\begin{array}{l}\text { Focus animal is changing direction of their gaze as } \\
\text { response to dominant threats. }\end{array}$ \\
\hline
\end{tabular}




\begin{tabular}{ccc}
\hline Avoidance & AV & $\begin{array}{c}\text { Focus animal is avoiding by moving away as response to } \\
\text { threats or disturbances. }\end{array}$ \\
\hline Freeze & FR & $\begin{array}{c}\text { Focus animal is static without movement as response to } \\
\text { threats or disturbances. }\end{array}$ \\
\hline Flee & FL & $\begin{array}{c}\text { Focus animal is moving quickly away from another, } \\
\text { usually in response to a threat or other aggressive } \\
\text { behaviour. }\end{array}$ \\
\hline Grimace/ Bared teeth & GM & Focus animal is showing teeth or grimacing. \\
\hline Out of Sight & OOS & Focus animal cannot be seen. \\
\hline Rummaging trash can/ trash & RM & Fest Behaviour animal is messing up trash or trash can. \\
\hline Littering & LT & Focus animal is discarding objects such as plastic bags. \\
\hline $\begin{array}{c}\text { Disturbing people } \\
\text { Damaging facilities or } \\
\text { properties }\end{array}$ & DP & $\begin{array}{c}\text { Focus animal is approaching, following or harassing } \\
\text { people. }\end{array}$ \\
\hline DM & $\begin{array}{c}\text { Focus animal is damaging facilities/ properties such as } \\
\text { pulling wire or cable, jumping on vehicles. }\end{array}$ \\
\hline
\end{tabular}

